\title{
Effects of sex and stocking density on the performance of broiler chickens in a sub- tropical environment
}

\author{
M. A. Madilindi ${ }^{1,2 \#}$, A. Mokobane ${ }^{1}$, P. B. Letwaba ${ }^{1}$, T. S. Tshilate ${ }^{1,2}$, C. B. Banga ${ }^{2}$, M. D. \\ Rambau $^{1,3}$, E. Bhebhe ${ }^{1}$ \& K. Benyi ${ }^{1}$ \\ ${ }^{1}$ Department of Animal Science, University of Venda, Private Bag X5050, Thohoyandou, 0950, South Africa \\ ${ }^{2}$ ARC-Animal Production Institute, Private Bag X2, Irene, 0062, South Africa \\ ${ }^{3}$ National Agricultural Marketing Council, Private Bag X935, Pretoria, 0001, South Africa
}

(Received 27 October 2017; Accepted 22 January 2018; First published online 15 February 2018)

\author{
Copyright resides with the authors in terms of the Creative Commons Attribution 4.0 South African Licence. \\ See: http://creativecommons.org/licenses/by/4.0/za \\ Condition of use: The user may copy, distribute, transmit and adapt the work, but must recognise the authors and the South \\ African Journal of Animal Science.
}

\begin{abstract}
The current study investigated the effects of sex and stocking density and their interaction on growth performance and carcass characteristics of broiler chickens in a semi-arid sub-tropical environment. A total of 1008 day-old Cobb Avian48 chicks, namely 462 males and 546 females, were reared at final stocking densities of 30,35 , and $40 \mathrm{~kg}$ bodyweight per square metre $\left(\mathrm{BW} / \mathrm{m}^{2}\right)$ corresponding to 44,51 and 59 , and 52, 61 and 69 chicks per pen for males and females, respectively, during a 42-day production period. The experiment was a $2 \times 3$ factorial completely randomized design, with each sex-stocking density combination being replicated three times. After the initial weighing, the birds were weighed individually [grams (g)] each week until the $42^{\text {nd }}$ day. At day 42 , four birds from each pen were randomly sampled and slaughtered, and carcass characteristics were measured after 48 hours, and expressed as percentages of bodyweight. Growth performance and carcass characteristic parameters were subjected to analysis of variance using the general linear model procedures of Minitab statistical software version 17. Treatment means were compared using Tukey's test (at $\alpha=0.05)$. Males gained more weight and were significantly heavier at slaughter age (2649 \pm $43.1 \mathrm{~g})$ than females $(2270 \pm 43.1 \mathrm{~g})$. There was a progressive reduction in feed intake with increasing stocking density, but neither sex nor stocking density influenced feed conversion ratio and mortality rate. Sex significantly affected dressing percentage and carcass parts percentages, namely breast, neck, shank, heart and abdominal fat and thigh, liver and gizzard. On the other hand, stocking density significantly influenced dressing percentage and carcass parts percentages such as breast, thigh, drumstick, neck, shank, liver and gizzard. There was a significant sex $x$ stocking density interaction effect on percentages of thigh and liver. It is therefore suggested that for efficient 42-day production cycles of broilers in the subtropics, Cobb Avian48 males reared at the stocking density of $40 \mathrm{~kg} \mathrm{BW} / \mathrm{m}^{2}$ could be considered the best option.
\end{abstract}

Keywords: Carcass characteristics, Cobb Avian48, feed conversion ratio, mortality

\#Corresponding author: matomemadilindi@gmail.com

\section{Introduction}

The objective of every broiler producer is to maximize the kilograms of chickens per unit of floor space, while simultaneously reducing losses due to overcrowding to attain optimum economic returns. Several studies have been conducted on the effects of stocking density on broiler performance, but the results have been conflicting. Some studies showed no significant influence of stocking density on broiler performance (Buijs et al., 2009; Rambau et al., 2016) while others demonstrated adverse effects of high stocking densities (Beg et al., 2011; Tong et al., 2012; Ligaraba et al., 2016; Siaga et al., 2017). Others, on the other hand, reported improved broiler performance with increased stocking density (Feddes et al., 2002). 
High stocking densities reduce the variable costs of production because more chickens are reared per unit of floor area. Thus, up to a critical point, profitability improves with increasing stocking density (Puron et al., 1995). Broiler producers therefore generally increase stocking density and sacrifice bird performance in an attempt to maximize returns per unit of floor area. However, circumstances are changing owing to bird welfare considerations. In Europe, stocking density has been fixed at $30 \mathrm{~kg} \mathrm{BW} / \mathrm{m}^{2}$ with an option to increase it to 39 or $42 \mathrm{~kg} \mathrm{BW} / \mathrm{m}^{2}$, provided set standards are met (European Commission, 2007). In the USA, the National Chicken Council (2005) established a voluntary welfare audit programme for broiler companies to follow. This programme stipulates a range of density rates based on final bodyweight from $31.8 \mathrm{~kg} \mathrm{BW} / \mathrm{m}^{2}$ for light broilers to $41.6 \mathrm{~kg} \mathrm{BW} / \mathrm{m}^{2}$ for roasters. A universal stocking density, however, is not attainable. Lower stocking densities are recommended for the tropics and subtropics than temperate areas, because of the stress caused by high ambient temperatures. Researchers (Sam et al., 2010; Shafey et al., 2013; Benyi et al., 2015; Siaga et al., 2017) reported that males consumed more feed, utilized feed more efficiently, grew faster, were heavier at slaughter age, and deposited less abdominal fat than females.

Currently, there is a paucity of information in tropical and sub-tropical conditions on the interaction effects of sex and stocking density on optimum broiler performance and carcass characteristics, since the recommended densities are based on research in temperate environments. This study, therefore, was carried out to examine the effects of sex and stocking density and their interaction on growth performance and carcass characteristics of broiler chickens in a sub-tropical environment.

\section{Materials and Methods}

This experiment was approved by the University of Venda Research Ethics Committee with registration number ARDF/15/ANS/1210. The study was conducted at the Poultry Facility of the School of Agriculture, University of Venda (latitude $22.9^{\circ} \mathrm{S}$, longitude $30.48^{\circ} \mathrm{S}$ ). The area experiences cold dry winters and hot rainy summers. The broiler house was a brick-walled building measuring $17 \mathrm{~m} \times 9 \mathrm{~m}$, similar to those used by small-scale broiler producers in the area. The width is built of bricks up to ceiling level, while the length is made of bricks up to one metre height and topped off by $2.5 \mathrm{~cm}$ wire mesh to the ceiling. Heavy plastic sheeting on top of the wire mesh is used to control air movement into and out of the building, since there are no fans in the facility or a barometer to measure relative humidity. The house was divided into 24 pens, of which only 18 were used for the study, each pen measuring $287 \mathrm{~cm} \times 150 \mathrm{~cm}$. The floor was covered with sawdust and each pen was equipped with two tube feeders, two automatic drinkers and two $175 \mathrm{~W}$ infra-red bulbs for heating. Minimum and maximum temperatures in the facility were recorded daily. The daily temperature in the house during the study ranged from 8 to $21^{\circ} \mathrm{C}$ with a mean of $18^{\circ} \mathrm{C}$.

A total of 1008 day-old Cobb Avian48 chicks, 462 males and 546 females, were available for the experiment. The experiment was a $2 \times 3$ factorial completely randomized design, and each sex-stocking density combination was replicated three times. On arrival at the facility, chicks were raised together to six days old (acclimatization period). On day 7 , the chicks of each sex were leg-banded, weighed individually, and randomly assigned to stocking densities of 30,35 , and $40 \mathrm{~kg} \mathrm{BW} / \mathrm{m}^{2}$ corresponding to 44,51 , and 59 ; and 52, 61, and 69 chicks per pen for males and females, respectively. The number of birds per pen was computed using 42 days bodyweight of 2.93 and $2.49 \mathrm{~kg}$ for males and females, respectively. The equation used to calculate the number of birds per pen needed for the stocking densities was birds/pen= [final treatment density $\left(\mathrm{kg} / \mathrm{m}^{2}\right) \times$ pen area $\left(\mathrm{m}^{2}\right)$ ] /projected final BW $(\mathrm{kg})$ (Dozier et al., 2006). The birds were fed a commercial broiler starter diet to 21 days, grower diet to 35 days and finisher diet to 42 days (Table 1 ).

Table 1 Chemical composition of commercial broiler starter, grower, finisher feeds used in this study

\begin{tabular}{lccc}
\hline Composition & Starter & Grower & Finisher \\
\hline Crude protein $(\mathrm{g} / \mathrm{kg})$ & 200 & 180 & 160 \\
ME $(\mathrm{MJ} / \mathrm{kg})$ & 12.76 & 13 & 13.20 \\
ME to CP rations $\left(\mathrm{MJ} \mathrm{g}^{-1}\right)$ & 0.06 & 0.07 & 0.08 \\
Fat $(\mathrm{g} / \mathrm{kg})$ & 25 & 25 & 25 \\
Fiber $(\mathrm{g} / \mathrm{kg})$ & 50 & 60 & 70 \\
Moisture $(\mathrm{g} / \mathrm{kg})$ & 120 & 120 & 120 \\
Calcium $(\mathrm{g} / \mathrm{kg})$ & 12 & 12 & 12 \\
Phosphorus $(\mathrm{g} / \mathrm{kg})$ & 6 & 5.50 & 5 \\
Lysine $(\mathrm{g} / \mathrm{kg})$ & 12 & 10 & 9
\end{tabular}

CP: crude protein, ME: metabolizable energy, g/kg: gram per kilogram, $\mathrm{MJ} \mathrm{g}^{-1}:$ megajoules per gram

Supplied by Meadow Feeds, Randfontein, South Africa 
Feed and water were offered ad libitum and lighting was provided 24 hours a day by $40 \mathrm{~W}$ fluorescent tubes throughout the study period. Feeder space/bird for male chicks was $5.9,5.1$, and $4.4 \mathrm{~cm}$, while for females it was $5.0,4.3$, and $3.8 \mathrm{~cm}$ for the stocking densities of 30,35 , and $40 \mathrm{~kg} \mathrm{BW} / \mathrm{m}^{2}$ respectively. The equation used to calculate the available feeder space per bird for each stocking density was feeder space/bird = circumference of the feeder $(\mathrm{cm}) /$ number of birds in each pen. The corresponding drinker space was $5.1,4.4$, and $3.8 \mathrm{~cm}$ for males, $4.3,3.7$, and $3.3 \mathrm{~cm}$, for females. After the initial weighing, the birds were weighed individually each week until 42 days. Prior to weighing, the birds were fasted for 12 hours. Feed consumed in each pen was recorded before the birds were weighed. Feed conversion ratio was calculated, and mortality was recorded daily. At day 42, four birds were randomly sampled from each pen, and slaughtered and carcass characteristics were measured after 48 hours of deep-freezing $\left(-18{ }^{\circ} \mathrm{C}\right)$, and expressed as percentages of bodyweight, as outlined by Benyi et al. (2015).

Pen means were used for bodyweights, bodyweight gains, feed intake, feed efficiency, and mortality rate, as well as dressing percentage weight and the percentage weights of the carcass parts. An analysis of variance was conducted, using the generalized linear model procedure of Minitab statistical software version 17 (Minitab, 2014), followed by standard means separation using Tukey's procedure $(\alpha=0.05)$.

\section{Results}

Table 2 shows results for performance during the first 21 days (starter period).

Table 2 Effects of sex and stocking density on broiler performance till the $21^{\text {st }}$ day of rearing (starter period)

\begin{tabular}{|c|c|c|c|c|c|c|c|c|}
\hline Sex & $\begin{array}{c}\text { Density } \\
\left(\mathrm{kg} \mathrm{BW} / \mathrm{m}^{2}\right)\end{array}$ & $\mathbf{N}$ & $\begin{array}{l}\text { IBW } \\
\text { (g) }\end{array}$ & $\begin{array}{c}\mathrm{BW}_{21} \\
(\mathrm{~g})\end{array}$ & $\begin{array}{l}\text { BWG }_{7-21} \\
(\mathrm{~g})\end{array}$ & $\begin{array}{c}F^{F_{7-21}} \\
\text { (g/b/day) }\end{array}$ & $\mathrm{FCR}_{7-21}$ & $\begin{array}{c}M_{7-21} \\
(\%)\end{array}$ \\
\hline \multirow[t]{3}{*}{ M } & 30 & 3 & 192 & 937 & 745 & 90 & 1.70 & 2.3 \\
\hline & 35 & 3 & 185 & 914 & 729 & 86 & 1.64 & 1.3 \\
\hline & 40 & 3 & 191 & 906 & 714 & 82 & 1.61 & 5.1 \\
\hline \multirow[t]{3}{*}{$F$} & 30 & 3 & 166 & 820 & 654 & 82 & 1.75 & 3.2 \\
\hline & 35 & 3 & 165 & 814 & 645 & 76 & 1.64 & 2.7 \\
\hline & 40 & 3 & 165 & 773 & 608 & 71 & 1.62 & 2.9 \\
\hline SEM & & & 6.2 & 11.7 & 8.6 & 0.9 & 0.02 & 0.15 \\
\hline \multicolumn{9}{|l|}{ Sex means } \\
\hline M & & 9 & $189^{a}$ & $919^{a}$ & $729^{a}$ & $86^{a}$ & 1.65 & 2.9 \\
\hline $\mathrm{F}$ & & 9 & $166^{b}$ & $802^{b}$ & $637^{b}$ & $76^{b}$ & 1.67 & 2.9 \\
\hline SEM & & & 3.6 & 6.8 & 4.9 & 0.5 & 0.011 & 0.86 \\
\hline & & & 179 & $878^{\mathrm{a}}$ & $699^{a}$ & $86^{a}$ & $1.73^{\mathrm{a}}$ & 2.7 \\
\hline & 35 & 6 & 175 & $864^{\mathrm{ab}}$ & $689^{a}$ & $81^{\mathrm{b}}$ & $1.64^{\mathrm{b}}$ & 2.0 \\
\hline & 40 & 6 & 178 & $839^{b}$ & $661^{\mathrm{b}}$ & $76^{\mathrm{c}}$ & $1.62^{\mathrm{b}}$ & 4.0 \\
\hline SEM & & & 4.4 & 8.3 & 6.0 & 0.6 & 0.013 & 1.06 \\
\hline Sex (S) & & & $* *$ & $\star *$ & $\star *$ & $\star \star$ & ns & ns \\
\hline Density (D) & & & ns & * & ** & $\star \star$ & $\star *$ & ns \\
\hline$S \times D$ & & & ns & ns & ns & ns & ns & ns \\
\hline
\end{tabular}

${ }^{\star *}: P<0.01 ;{ }^{*}: P<0.05 ;$ ns: non-significant at $P>0.05$

abc Column means with different superscripts differ significantly at $P<0.05$

$\mathrm{N}$ : number of observations, M: male, F: female, IBW: initial body weight, BW 21 : body weight at day $21, \mathrm{BWG}_{7-21}$ : body weight gain from 7 to 21 days, $\mathrm{FC}_{7-21}$ : feed consumption from 7 to 21 days, $\mathrm{FCR}_{7-21}$ : feed conversion ratio from 7 to 21 days, $\mathrm{MR}_{7-21}$ : mortality rate from 7 to 21 days, S x D: sex x stocking density interaction, g: gram, g/b/day: grams/bird/day, $\%$ : percentage, SEM: standard error mean

Sex had an effect $(P<0.01)$ on the initial bodyweight, 21 days bodyweight, bodyweight gain and feed consumption, but had no effect $(P>0.05)$ on feed conversion ratio and mortality rate. At both initial stage and 21 days old, male birds were heavier, consumed more feed, and gained more bodyweight than females. Stocking density had no effect $(P>0.05)$ on mortality rate but affected bodyweight $(P<0.05)$, as well as bodyweight gain, feed consumption, and feed conversion ratio (all at $P<0.01$ ). Body weight at 21 days and feed consumption, decreased progressively with increasing stocking density. Birds raised at stocking 
densities of 30 and $35 \mathrm{~kg} \mathrm{BW} / \mathrm{m}^{2}$ did not differ $(P>0.05)$ in bodyweight gain but gained more $(P<0.01)$ bodyweight than those reared at the density of $40 \mathrm{~kg} \mathrm{BW} / \mathrm{m}^{2}$. There was no difference $(P>0.05)$ in feed conversion ratio between birds raised at 35 and $40 \mathrm{~kg} \mathrm{BW} / \mathrm{m}^{2}$; however, both utilized feed more efficiently $(P$ $<0.01$ ) than those raised at the density of $30 \mathrm{~kg} \mathrm{BW} / \mathrm{m}^{2}$.

Results for the grower period (22-35 days) are summarized in Table 3.

Table 3 Effects of sex and stocking density on broiler performance from 22 to 35 days of rearing (grower period)

\begin{tabular}{|c|c|c|c|c|c|c|c|}
\hline Sex & $\begin{array}{c}\text { Density } \\
\left(\mathrm{kg} \mathrm{BW} / \mathrm{m}^{2}\right)\end{array}$ & $\mathbf{N}$ & $\begin{array}{l}\mathrm{BW}_{35} \\
(\mathrm{~g})\end{array}$ & $\begin{array}{c}\text { BWG }_{22-35} \\
\text { (g) }\end{array}$ & $\begin{array}{c}\mathrm{FC}_{22-35} \\
\text { (g/b/day) }\end{array}$ & $\mathrm{FCR}_{22-35}$ & $\begin{array}{c}\text { MR }_{22-35} \\
(\%)\end{array}$ \\
\hline \multirow[t]{3}{*}{ M } & 30 & 3 & 2220 & 1284 & 189 & 2.07 & 6.1 \\
\hline & 35 & 3 & 2194 & 1280 & 176 & 1.92 & 4.6 \\
\hline & 40 & 3 & 2144 & 1238 & 175 & 1.98 & 2.3 \\
\hline \multirow[t]{3}{*}{$\mathrm{F}$} & 30 & 3 & 1970 & 1151 & 169 & 2.06 & 5.1 \\
\hline & 35 & 3 & 1902 & 1089 & 156 & 2.01 & 2.7 \\
\hline & 40 & 3 & 1822 & 1049 & 147 & 1.98 & 4.3 \\
\hline SEM & & & 37.8 & 38.9 & 3.4 & 0.79 & 1.9 \\
\hline \multicolumn{8}{|l|}{ Sex means } \\
\hline M & & 9 & $2186^{a}$ & $1267^{\mathrm{a}}$ & $180^{\mathrm{a}}$ & 1.99 & 4.3 \\
\hline $\mathrm{F}$ & & 9 & $1898^{\mathrm{b}}$ & $1096^{b}$ & $157^{\mathrm{b}}$ & 2.02 & 4.1 \\
\hline SEM & & & 21.8 & 22.5 & 1.9 & 0.04 & 1.1 \\
\hline \multicolumn{8}{|l|}{ Density means } \\
\hline & 30 & 6 & $2095^{a}$ & 1217 & $179^{\mathrm{a}}$ & 2.06 & 5.6 \\
\hline & 35 & 6 & $2048^{\mathrm{ab}}$ & 1184 & $166^{\mathrm{b}}$ & 1.97 & 3.7 \\
\hline & 40 & 6 & $1983^{b}$ & 1144 & $161^{\mathrm{b}}$ & 1.98 & 3.3 \\
\hline SEM & & & 26.7 & 27.5 & 2.4 & 0.06 & 1.4 \\
\hline $\operatorname{Sex}(S)$ & & & $\star \star *$ & $\star \star \star$ & $\star \star *$ & ns & ns \\
\hline Density (D) & & & * & ns & ** & ns & ns \\
\hline$S \times D$ & & & ns & ns & ns & ns & ns \\
\hline
\end{tabular}

**: $P<0.01 ; *: P<0.05 ;$ ns: non-significant at $P>0.05$

${ }^{\text {ab }}$ Column means with different superscripts differ significantly at $P<0.05$

$\mathrm{N}$ : number of observations, $\mathrm{M}$ : male, $\mathrm{F}$ : female, $\mathrm{BW}_{35}$ : body weight at day $35, \mathrm{BWG}_{22-35}$ : body weight gain from 22 to 35 days, $\mathrm{FC}_{22-35}$ : feed consumption from 22 to 35 days, $\mathrm{FCR}_{22-35}$ : feed conversion ratio from 22 to 35 days, $\mathrm{MR}_{22-35}$ : mortality rate from 22 to 35 days, S x D: sex $x$ stocking density interaction, g: gram, g/b/day: grams/bird/day, \%: percentage, SEM: standard error mean

Sex influenced $(P<0.01) 35$ days bodyweight, bodyweight gain and feed consumption, but did not affect $(P>0.05)$ feed conversion ratio and mortality rate. Males consumed more feed, grew faster and were heavier at the end of the period than females. Stocking density affected 35 days bodyweight $(P<0.05)$ and feed consumption $(P<0.01)$, but did not affect $(P>0.05)$ bodyweight gain, feed conversion ratio and mortality rate. Birds reared at the stocking density of $30 \mathrm{~kg} \mathrm{BW} / \mathrm{m}^{2}$ consumed more feed and were heavier at 35 days of the rearing period than those raised at densities of 35 and $40 \mathrm{~kg} \mathrm{BW} / \mathrm{m}^{2}$; however, the two latter groups did not differ $(P>0.05)$ in feed consumption and 35 days bodyweight $(P>0.05)$.

Table 4 presents results for the finishing period (36-42 days). There were influences of sex on mortality rate, 42 days bodyweight (all at $P<0.01$ ), bodyweight gain and feed consumption (all at $P<0.05$ ), but not on feed conversion ratio $(P>0.05)$. Males consumed more feed, gained more bodyweight and were heavier at 42 days but had a higher mortality rate than females. Stocking density affected feed consumption $(P<0.01)$ and feed conversion ratio $(P<0.05)$ but had no influence on 42 days bodyweight, bodyweight gains and mortality rate $(P>0.05)$. Birds reared at the stocking densities of 30 and $35 \mathrm{~kg} \mathrm{BW} / \mathrm{m}^{2}$ did not differ in feed consumption but consumed more feed than those raised at a stocking density of $40 \mathrm{~kg} \mathrm{BW} / \mathrm{m}^{2}(P$ $<0.05)$. Birds reared at the density of $40 \mathrm{~kg} \mathrm{BW} / \mathrm{m}^{2}$ utilized feed more efficiently, followed by those reared at $30 \mathrm{~kg} \mathrm{BW} / \mathrm{m}^{2}$.

A summary of the results for the entire study period is given in Table 5 . Sex influenced $(P<0.01)$ bodyweight gain, with males growing more than females. Stocking density had an effect $(P<0.05)$ on feed consumption, with a progressive reduction in feed consumption as stocking density increased. 
Table 4 Effects of sex and stocking density on broiler performance from 36 to 42 days of rearing (finisher period)

\begin{tabular}{|c|c|c|c|c|c|c|c|}
\hline Sex & $\begin{array}{c}\text { Density } \\
\left(\mathrm{kg} \mathrm{BW} / \mathrm{m}^{2}\right)\end{array}$ & $\mathbf{N}$ & $\begin{array}{c}\mathrm{BW}_{42} \\
(\mathrm{~g})\end{array}$ & $\begin{array}{c}\text { BWG }_{36-42} \\
(\mathrm{~g})\end{array}$ & $\begin{array}{c}\mathrm{FC}_{36-42} \\
\text { (g/b/day) }\end{array}$ & $\mathrm{FCR}_{36-42}$ & $\begin{array}{c}\text { MR }_{36-42} \\
(\%)\end{array}$ \\
\hline \multirow[t]{3}{*}{ M } & 30 & 3 & 2892 & 672 & 164 & 1.71 & 5.3 \\
\hline & 35 & 3 & 2818 & 624 & 158 & 1.78 & 5.9 \\
\hline & 40 & 3 & 2892 & 748 & 143 & 1.41 & 2.8 \\
\hline \multirow[t]{3}{*}{$\mathrm{F}$} & 30 & 3 & 2532 & 561 & 148 & 1.86 & 0.6 \\
\hline & 35 & 3 & 2432 & 529 & 141 & 1.87 & 1.1 \\
\hline & 40 & 3 & 2349 & 527 & 122 & 1.63 & 0.5 \\
\hline SEM & & & 66.6 & 58.9 & 3.4 & 0.11 & 1.07 \\
\hline \multicolumn{8}{|l|}{ Sex means } \\
\hline $\mathrm{M}$ & & 9 & $2867^{a}$ & $681^{a}$ & $155^{\mathrm{a}}$ & 1.63 & $4.7^{\mathrm{a}}$ \\
\hline $\mathrm{F}$ & & 9 & $2437^{b}$ & $539^{b}$ & $137^{b}$ & 1.79 & $0.7^{b}$ \\
\hline SEM & & & 38.4 & 34.0 & 1.9 & 0.06 & 1.11 \\
\hline \multicolumn{8}{|c|}{ Density means } \\
\hline & 30 & 6 & 2712 & 616 & $156^{\mathrm{a}}$ & $1.79^{\mathrm{ab}}$ & 3.0 \\
\hline & 35 & 6 & 2625 & 577 & $149^{a}$ & $1.82^{\mathrm{a}}$ & 3.5 \\
\hline & 40 & 6 & 2620 & 638 & $132^{b}$ & $1.52^{b}$ & 1.7 \\
\hline SEM & & & 47.1 & 41.6 & 2.4 & 0.08 & 0.76 \\
\hline $\operatorname{Sex}(S)$ & & & $* *$ & * & * & ns & $\star *$ \\
\hline Density (D) & & & ns & $* *$ & * & ns & ns \\
\hline$S \times D$ & & & ns & ns & ns & ns & ns \\
\hline
\end{tabular}

**: $P<0.01 ; *: P<0.05 ;$ ns: non-significant at $P>0.05$

ab Column means with different superscripts differ significantly at $P<0.05$

$\mathrm{N}$ : number of observations, $\mathrm{M}$ : male, $\mathrm{F}$ : female, $\mathrm{BW}_{42}$ : bodyweight at day $42, \mathrm{BWG}_{36-42}$ : bodyweight gain from 36 to 42 days, $\mathrm{FC}_{36-42}$ : feed consumption from 36 to 42 days, $\mathrm{FCR}_{36-42}$ : feed conversion ratio from 36 to 42 days, $\mathrm{MR}_{36-42}$ : mortality rate from 36 to 42 days, $S \times$ D: sex $x$ stocking density interaction, g: gram, g/b/day: grams/bird/day, \%: percentage, SEM: standard error of mean

The results for carcass traits are summarized in Table 6 . There were effects of sex on dressing, breast, neck, and shank percentages $(P<0.01)$, and thigh percentage $(P<0.05)$, but not back, wing, and drumstick percentages $(P>0.05)$. Where significant differences existed, females had consistently higher carcass component percentages than males. Stocking density affected dressing, breast, thigh, drumstick, neck and shank percentages $(P<0.01)$. Birds reared at $35 \mathrm{~kg} \mathrm{BW} / \mathrm{m}^{2}$ stocking density recorded the highest dressing and breast percentages, while those raised at $40 \mathrm{~kg} \mathrm{BW} / \mathrm{m}^{2}$ had the lowest. There was no difference $(P>0.05)$ in thigh percentage between birds reared at the two lower stocking densities; however, these had higher percentages than those reared at the highest density. Birds reared at the stocking densities of 35 and $40 \mathrm{~kg} \mathrm{BW} / \mathrm{m}^{2}$ did not differ in drumstick percentage, but had higher mean percentages compared with the lowest stocking density. There was a progressive reduction in neck percentage with increasing stocking density, while birds reared at the density of $35 \mathrm{~kg} \mathrm{BW} / \mathrm{m}^{2}$ had the highest mean shank percentage and those reared at the density of $30 \mathrm{~kg} \mathrm{BW} / \mathrm{m}^{2}$ had the lowest. Sex by stocking density interaction effect influenced thigh percentage $(P<0.05)$. 
Table 5 Effects of sex and stocking density on broiler performance from 7 to 42 days of rearing (study period)

\begin{tabular}{|c|c|c|c|c|c|c|}
\hline Sex & $\begin{array}{c}\text { Density } \\
\left(\mathrm{kg} \mathrm{BW} / \mathrm{m}^{2}\right)\end{array}$ & $\mathbf{N}$ & $\begin{array}{c}\text { BWG }_{7-42} \\
(\mathrm{~g})\end{array}$ & $\begin{array}{c}F_{7-42} \\
\text { (g/b/day) }\end{array}$ & $\mathrm{FCR}_{7-42}$ & $\begin{array}{c}\text { MR7-42 } \\
(\%)\end{array}$ \\
\hline \multirow[t]{3}{*}{ M } & 30 & 3 & 2616 & 144 & 1.9 & 13.6 \\
\hline & 35 & 3 & 2633 & 135 & 1.8 & 11.8 \\
\hline & 40 & 3 & 2699 & 131 & 1.7 & 10.2 \\
\hline \multirow[t]{3}{*}{$\mathrm{F}$} & 30 & 3 & 2359 & 149 & 2.2 & 9.0 \\
\hline & 35 & 3 & 2266 & 121 & 1.9 & 7.7 \\
\hline & 40 & 3 & 2184 & 111 & 1.8 & 6.6 \\
\hline SEM & & & 74.7 & 8.2 & 0.1 & 2.5 \\
\hline \multicolumn{7}{|l|}{ Sex means } \\
\hline M & & 9 & $2678^{a}$ & 136 & 1.8 & 11.9 \\
\hline $\mathrm{F}$ & & 9 & $2272^{b}$ & 127 & 2.0 & 7.6 \\
\hline SEM & & & 43.1 & 4.7 & 0.1 & 1.4 \\
\hline \multicolumn{7}{|l|}{ Density means } \\
\hline & 30 & 6 & 2487 & $146^{\mathrm{a}}$ & 2.1 & 11.3 \\
\hline & 35 & 6 & 2450 & $128^{\mathrm{ab}}$ & 1.8 & 9.2 \\
\hline & 40 & 6 & 2441 & $121^{\mathrm{b}}$ & 1.7 & 8.9 \\
\hline SEM & & & 42.8 & 5.8 & 0.1 & 1.8 \\
\hline $\operatorname{Sex}(S)$ & & & $\star \star$ & $\mathrm{ns}$ & $\mathrm{ns}$ & ns \\
\hline Density (D) & & & $* *$ & ns & ns & ns \\
\hline$S \times D$ & & & ns & ns & ns & ns \\
\hline
\end{tabular}

${ }^{\star *}: P<0.01 ;{ }^{*}: P<0.05 ;$ ns: non-significant at $P>0.05$.

${ }^{\text {ab }}$ Column means with different superscripts differ significantly at $P<0.05$.

$\mathrm{N}$ : number of observations, $\mathrm{M}$ : male, $\mathrm{F}$ : female, $\mathrm{BWG}_{7-42}$ : bodyweight gain from 7 to 42 days, $\mathrm{FC}_{7-42}$ : feed consumption from 7 to 42 days, $F_{7-42}$ : feed conversion ratio from 7 to 42 days, MR $\mathrm{MR}_{7-42}$ : mortality rate from 7 to 42 days, $S \times D$ : sex $x$ stocking density interaction, g: gram, g/b/day: grams/bird/day, \%: percentage, SEM: standard error of mean

Table 6 Effects of sex and stocking density on broiler carcass percentages

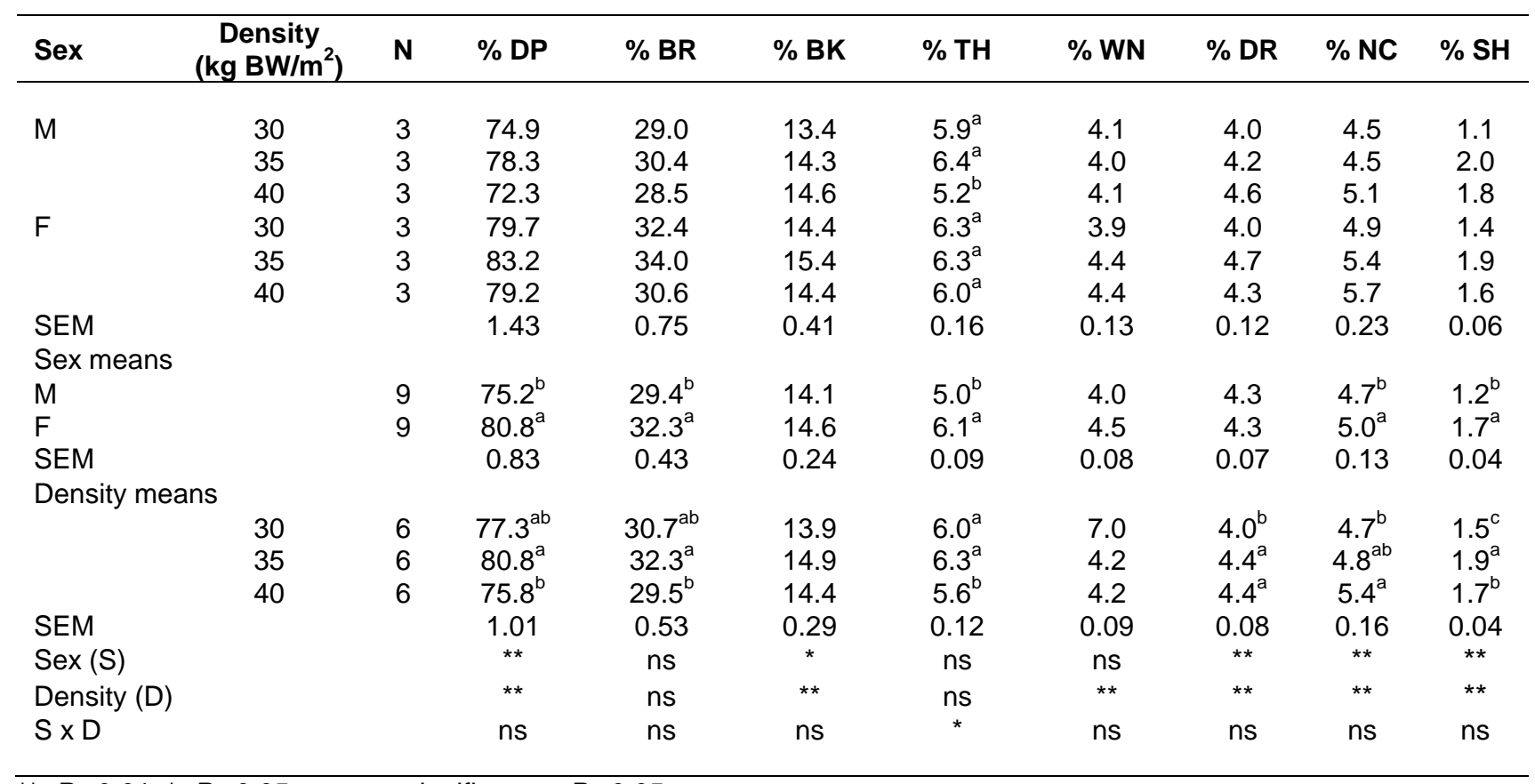

**: $P<0.01 ;{ }^{*}: P<0.05$; ns: non-significant at $P>0.05$.

abc Column means with different superscripts differ significantly at $P<0.05$.

$\mathrm{N}$ : number of observations, M: male, F: female, DP: dressing percentage, BR: breast, BK: back, TH: thigh, WN: wing, DR: drumstick, NC: neck, SH: shank, S x D: sex x stocking density interaction, \%: percentage, SEM: standard error of mean 
Table 7 shows the results for giblet (liver, gizzard and heart) and abdominal fat percentages. Sex had effects on liver and gizzard percentage $(P<0.05)$ as well as heart and abdominal fat percentage $(P<0.01)$, with higher means for females than males in all the traits. Stocking density affected $(P<0.01)$ liver and gizzard percentage but had no effects on heart and abdominal fat percentage $(P>0.05)$. Birds reared at the stocking densities of 35 and $40 \mathrm{~kg} \mathrm{BW} / \mathrm{m}^{2}$ did not significantly differ in liver percentage but had higher percentages than those reared at the density of $30 \mathrm{~kg} \mathrm{BW} / \mathrm{m}^{2}$. There was a progressive increase in gizzard percentage with increasing stocking density. Sex by stocking density interaction effect affected $(P<0.05)$ liver weight percentage.

Table 7 Effects of sex and stocking density on broiler giblets and abdominal fat percentages

\begin{tabular}{|c|c|c|c|c|c|c|}
\hline Sex & $\begin{array}{c}\text { Density } \\
\left(\mathrm{kg} \mathrm{BW} / \mathrm{m}^{2}\right)\end{array}$ & $\mathbf{N}$ & $\%$ LV & $\%$ GZ & $\%$ HR & $\%$ ABD \\
\hline \multirow[t]{3}{*}{ M } & 30 & 3 & $1.64^{\mathrm{C}}$ & 0.97 & 0.42 & 1.85 \\
\hline & 35 & 3 & $1.86^{\mathrm{ab}}$ & 1.11 & 0.42 & $1.69^{b}$ \\
\hline & 40 & 3 & $1.56^{\mathrm{C}}$ & 1.31 & 0.46 & 1.66 \\
\hline \multirow[t]{2}{*}{$\mathrm{F}$} & 30 & 3 & $1.65^{\mathrm{abc}}$ & 1.12 & 0.50 & 2.27 \\
\hline & 35 & 3 & $1.91^{\mathrm{a}}$ & 1.27 & 0.53 & 1.93 \\
\hline SEM & & & 0.07 & 0.07 & 0.03 & 0.11 \\
\hline \multicolumn{7}{|l|}{ Sex means } \\
\hline M & & 9 & $1.68^{\mathrm{b}}$ & $1.13^{\mathrm{b}}$ & $0.44^{\mathrm{b}}$ & $1.73^{\mathrm{b}}$ \\
\hline $\mathrm{F}$ & & 9 & $1.81^{\mathrm{a}}$ & $1.27^{\mathrm{a}}$ & $0.52^{\mathrm{a}}$ & $2.13^{\mathrm{a}}$ \\
\hline SEM & & & 0.04 & 0.04 & 0.02 & 0.06 \\
\hline \multicolumn{7}{|l|}{ Density means } \\
\hline & $\begin{array}{l}30 \\
35\end{array}$ & $\begin{array}{l}6 \\
6\end{array}$ & $\begin{array}{l}1.64^{\mathrm{o}} \\
1.88^{\mathrm{a}}\end{array}$ & $1.04^{\mathrm{ab}}$ & $\begin{array}{l}0.46 \\
0.47\end{array}$ & $\begin{array}{l}2.06 \\
1.81\end{array}$ \\
\hline & 40 & 6 & $1.72^{\mathrm{a}}$ & $1.37^{\mathrm{a}}$ & 0.50 & 1.92 \\
\hline SEM & & & 0.05 & 0.05 & 0.02 & 0.08 \\
\hline $\operatorname{Sex}(S)$ & & & * & * & $* *$ & $* *$ \\
\hline Density (D) & & & ** & ns & ns & ** \\
\hline$S \times D$ & & & * & ns & ns & ns \\
\hline
\end{tabular}

${ }^{* *}: P<0.01 ;{ }^{*}: P<0.05$; ns: non-significant at $P>0.05$

abc Column means with different superscripts differ significantly at $P<0.05$

$\mathrm{N}$ : number of observations, M: male, F: female, LV: liver, GZ: gizzard, HR: heart, ABD: abdominal fat, S x D:

sex $x$ stocking density interaction, \%: percentage, SEM: standard error of mean

\section{Discussion}

Regardless of treatments, all birds had more than $2 \mathrm{~kg}$ average weight at the end of the 42-day experimental period. This indicates that the conditions were conducive to producing broilers, given that appropriate management practices were followed. However, mortality rate was an issue since males reared at stocking density of $30 \mathrm{~kg} \mathrm{BW} / \mathrm{m}^{2}$ recorded the highest mortality rate of $13.6 \%$.

The significant differences between male and female birds in bodyweight and bodyweight gain throughout the experimental period, as well as feed consumption and mortality rate during the finisher period are consistent with earlier reports (Sam et al., 2010; López et al., 2011). The superior bodyweight gain and subsequent heavier weight at all stages of growth for the male birds could be attributed to physiological differences between the sexes in bodyweight gain and feed consumption. A positive genetic correlation is known to exist between these traits (Chambers, 1990; Aggrey et al., 2010). The similarity between the sexes in feed conversion ratio at all the stages of production, despite the higher feed consumption of males, suggests that the two sexes utilized feed with the same degree of efficiency. This observation contradicts previous studies that showed that males utilized feed more efficiently than females (Sam et al., 2010; Shafey et al., 2013). This could be owing to environmental differences or the genetic makeup of birds used in the experiments. The higher mortality rate in males than females observed during the finisher period could probably be because of the genetic habits of males, which cause them to be aggressive towards one another. 
The significant effects of stocking density on feed consumption during the rearing period were in agreement with previous studies (Yakubu et al., 2010; Beg et al., 2011; Rambau et al., 2016; Siaga et al., 2017), namely bodyweight gain during the starter and grower periods, and feed conversion ratio during the finisher period, These studies indicated that high stocking densities reduced feed consumption, bodyweight gain and market weight, and improved feed conversion ratio. However, the extent of reduction or improvement depended on how high the particular density was. Reduced bodyweight gain at high stocking densities could be attributed partly to decreased feed consumption, owing to physical competition for access to feeders. The non-significant effects of stocking density on mortality rate concur with those of Meluzzi \& Sirri (2008), but contradict other studies (Onbasilar, 2008; Yakubu et al., 2010).

Higher dressing percentage, weight percentage of breast, thigh, neck, and shank were observed in females than males. The higher live weight of the male birds resulted to their lower dressing percentage and carcass part weight percentage compared with female birds. This indicated that carcass part weight percentage has an indirectly proportional relationship with the live weight of these birds. In this study, male birds scored significantly higher live weight than females. However, additional live weight could have resulted from feathers, blood and intestines, which are heavier in male than in female birds. Consequently, this could have resulted in the higher difference between live weight and carcass weight of male than females, which leads to lower weight percentages of male carcass parts than in females when carcass parts were expressed as live weight percentage. Shafey et al. (2013) reported a positive correlation of live weight and the carcass part weights. However, the present findings are indirectly proportional when carcass parts are expressed as live weight percentages. Similarly, Ojedapo et al. (2008) reported that female WadiRoss and Ross birds had higher percentage carcass and breast weight percentages at 12 weeks old than their male counterparts. In an earlier study, Markley et al. (1980) found significant differences between sexes, with females having greater breast weight and backs, but smaller legs. On the contrary, Hassani-Vaslan (2010) reported higher percentages of breast, thigh and heart in males than in females, while Olawumi \& Fagbuaro (2011) observed higher eviscerated weight, back muscle weight, thigh muscle and drumstick weights in males than in females. Isidahomen et al. (2012) noted that males had higher percentages of head, neck, wing, thigh, drumstick breast and back than females. According to Shafey et al. (2013), the higher the live weight, the higher the weight percentages of the carcass parts. This is supported by numerous studies, which show that male birds score higher weights of carcass parts than females (López et al., 2011; Shim et al., 2012; Benyi et al., 2015). This has been attributed to sexual dimorphism, which generally favours males, especially in poultry (llori et al., 2010; Peters, 2010). The current findings, however, are not in line with this theory because the authors found males to be heavier, but with lower carcass component percentages than female birds.

There was indirectly proportional relationship between stocking density and the carcass percentage of the birds, hence the lower to intermediate stocking density (30 and $35 \mathrm{~kg} \mathrm{BW} / \mathrm{m}^{2}$ ), the significantly higher percentages of carcass, breast, thigh, drumstick and shank for birds, while higher stocking density $(40 \mathrm{~kg}$ $\mathrm{BW} / \mathrm{m}^{2}$ ) resulted in significantly lower carcass percentage. These results concur with the findings of Beg et al. (2011). On the other hand, other studies (Feddes et al., 2002; Beg et al., 2011; Rambau et al., 2016) reported that percentages of thigh, drumstick and neck increased as stocking density increased. Ligaraba et al. (2016), however, observed no significant effects of stocking density on all the carcass traits measured, while Siaga et al. (2017) observed significant effects on breasts only. These discrepancies could be attributed to other factors such as season in which the birds were reared, genotypes and feeding regime. This study also reported significant effects of sex $x$ stocking density interaction on thigh percentage weight, suggesting that raising male birds at a stocking density of $40 \mathrm{BW} / \mathrm{m}^{2}$ would yield relatively lower thigh percentage weight than female birds. However, the interaction did not affect the percentage weights of the rest of carcass characteristics. This emphasizes that no significant influence would result in carcass characteristics weight percentages when raising male or female birds at low, intermediate or high stocking density. Both sexes would yield equal carcass characteristics weight percentages at different stocking densities except for thigh.

Reports on the effects of sex on percentages of edible giblets and abdominal fat are inconsistent (Rondelli et al., 2003; Bogosavljević-Bošković et al., 2006; Azahan et al., 2007; Nikolova et al., 2007). Brake et al. (1995) reported that the growth rate of muscle tissue (the main carcass component) increases faster than growth rates of internal organs and non-edible parts. In the current study, weight percentages of liver, gizzard, heart and abdominal fat were influenced by sex, with higher means for females than males. This agrees in part with Azahan et al. (2007) and Nikolova et al. (2007), who noted that female carcasses had higher fat than those of males. Le Bihan-Duval (1998) suggested that this could be because of the greater impact of hormones for fatness in females than males. It could also be because females start to store fat at an earlier age than males. Females were found to start storing fats from six weeks old compared with eight 
weeks for males (Almasi et al., 2012). Rondelli et al. (2003), Bogosavljević-Bošković et al. (2006) and Siaga et al. (2017), on the contrary, showed that there were no significant differences in abdominal fat between males and females.

Stocking density affected gizzard and liver percentages significantly, with higher mean weight percentages in birds reared at the medium $\left(35 \mathrm{~kg} \mathrm{BW} / \mathrm{m}^{2}\right)$ and higher $\left(40 \mathrm{~kg} \mathrm{BW} / \mathrm{m}^{2}\right)$ densities of this study. This is probably because at high stocking densities overcrowding causes birds to consume feed quickly. As a result, the gizzard becomes bigger or develops faster in order to grind larger quantities of feed in a short period. However, in the present study, stocking density had no impact on the percentage of heart. Ligaraba et al. (2016), Rambau et al. (2016) and Siaga et al. (2017) reported similar observations that stocking density had no effect on heart percentage. On the contrary, Onbasilar et al. (2008) reported a higher percentage of heart of broiler at high stocking density owing to rapid respiration caused by too much litter. However, the litter of birds in a higher stocking density should have been managed properly to avoid the bias across the experiment.

\section{Conclusions}

The current study suggests that under semi-arid subtropical conditions, male Cobb Avian48 birds could perform better than females. Male birds achieved heavier live weight at slaughter age (42 days) and deposited less fat than females, which is noteworthy, because less fat would comply with consumers' preferences and their health. When birds were fed ad libitum, higher stocking density resulted in a reduction in feed consumption, with a superior feed conversion ratio compared with the medium and lower stocking density during the finisher period. Neither sex nor stocking density influenced the mortality rate during the entire rearing period. Stocking density significantly influenced weight percentages of carcass, breast, thigh, drumstick, neck, shank, liver, and gizzard. Sex $\times$ stocking density interaction effect affected weight percentages of thigh and liver of the birds. Overall, it is suggested that for efficient broiler production in the subtropics, for a 42-day production cycle, Cobb Avian48 males reared at a stocking density of $40 \mathrm{~kg} \mathrm{BW} / \mathrm{m}^{2}$ could be regarded as the best option. A female Cobb Avian48 could also be considered a significant option when raised at 35 and $40 \mathrm{~kg} \mathrm{BW} / \mathrm{m}^{2}$ with special focus on selected carcass characteristic weight percentages.

\section{Acknowledgements}

The authors would like to gratefully acknowledge National Research Foundation and Department of Animal Science, School of Agriculture, University of Venda for financial support.

\section{Authors' Contributions}

Conception and design of experiment was done by MAM and KB. MAM, AM and PBL conducted the experiment and analysed data with KB, MDR and TST. All authors participated in interpretation of results, writing, and integration of the manuscript. Critical revision and final approval of version to be published was also done by all authors.

\section{Conflict of Interest Declaration}

Authors confirm that there were no conflicts of interest, this manuscript has been read and approved by all authors and that the order of authors listed in the manuscript has been approved by all of them.

\section{References}

Aggrey, S.E., Karmuah, A.D., Sebastian, B.N. \& Anthony, B., 2010. Genetic properties of feed efficiency in meat-type chickens. Genet. Sel. Evol. 42, 25.

Almasi, A., Suto, Z., Budai, Z., Donko, T., Milisits, G. \& Horn, P., 2012. Effect of age, sex and strain on growth, body composition and carcass characteristics of dual purpose type chicken. World Poultry Congress 2012, Salvador, Bahia, Brazil, 5-8 August 2012. Worlds Poult. Sci. J. 68 (1), 285-288.

Azahan, E.A.E., Marhi, A.M. \& Norazha, M., 2007. Evaluation of the effects of sex on growth and carcass characteristics of broilers. Malays. J. Trop. Agric. \& Fd. Sc. 35, 313-318.

Beg, M.A.H., Baqui, M.A., Sarker, N.R. \& Hossain, M.M., 2011. Effect of stocking and feeding regime on performance of broiler chicken in summer season. Int. J. Poult. Sci. 10, 365-375.

Benyi, K., Tshilate, T.S., Netshipale, A.J. \& Mahlako, K.T., 2015. Effects of genotype and sex on the growth performance and carcass characteristics of broiler chickens. Trop. Anim. Health Prod. 47, 1225-1231.

Bogosavljević-Bošković, S., Kurćubić, V., Petrović, M.D. \& Radović, V., 2006. The effect of sex and rearing system on carcass composition and cut yields of broiler chickens. Czech. J. Anim. Sci. 51, 31-38.

Brake, J., Havenstein, G.B., Ferket P.R, Rives, D.V. \& Giesbrecht, F.G., 1995. Relationship of sex, strain and bodyweight to carcass yield and offal production in turkeys. Poult. Sci. 74, 161-168.

Buijs, S., Keeling, L., Rettenbacher, S., van Poucke, E. \& Tuyttens, A.M., 2009. Stocking density effects on broiler welfare: Identifying sensitive ranges for different indicators. Poult. Sci. 88, 1536-1543. 
Chambers, J.R., 1990. Genetics of growth and meat production in chickens. In: R.D. Crawford (ed). Poultry breeding and genetics, Elsevier Science B. V., Netherlands, pp. 599-943.

Dozier, W.A., Thaxton, J.P., Purswell, J.L., Olarenwaju, H.A., Branton, S.L., \& Roush, W.B., 2006. Stocking density effects on male broilers grown to 1.8 kilograms of body weight. Poult. Sci. 85, 344-351.

European Commission, 2007. Council Directive of 28 June 2007, laying down minimum rules for the protection of chickens kept for meat production 2007/43/EC In: Official Journal, L182. 12/07/2007, pp. 19-28.

Feddes, J.J., Emmanuel, E.J. \& Zuidloft, M.J., 2002. Broiler performance, body weight variance, feed and water intake and carcass quality at different stocking densities. Poult. Sci. 81, 774-779.

Hassani-Vaslan, S.I., Gollan, A.R.A, Motaghini, G., Namvari, M. \& Hamedi, M., 2010. Comparison of growth performance and carcass characteristics of broiler chicken fed diets with various energy and constant energy to protein ratio. J. Anim. Vet. Adv. 9, 2565-2570.

Ilori, B.M., Peters, S.O., Ikeobi, C.O.N., Bamgbose, A.M. Isidahomen, C.E \& Ozoje, M.O., 2010. Comparative assessment of growth in pure and crossbred turkeys in a humid tropical environment. Int. J. Poult. Sci. 9, 368375.

Isidahomen, C.E., Ilori. B.M. \& Akano, K., 2012. Genetic and sex differences in carcass traits of Nigerian indigenous chickens. J. Anim. Sci. Adv. 2, 637-648.

Ligaraba, T.J., Benyi, K. \& Baloyi, J.J., 2016. Effects of genotype and stocking density on broiler performance under three feeding regimes. Trop. Anim. Health Prod. 8(6), 1227-1234.

Le Bihan-Duval, E., Mignon-Grasteau S., Millet, N. \& Beaumont, C., 1998. Genetic analysis of selection on increased body weight and breast muscle weight as well as on limited abdominal fat weight. Br. Poult. Sci. 39, 346-353.

López, K.P., Schilling, M.W. \& Corzo, A., 2011. Broiler genetic strain and sex effects on meat characteristics. Poult. Sci. 90, 1105-1111.

Markley, J.W., Weinland, B.T. Malone, G.W. \& Chaloupka, G.W., 1980. Evaluation of five commercial broiler crosses 2. Eviscerated yield and component parts. Poult. Sci. 59, 1755-1760.

Meluzzi, A. \& Sirri, F., 2008. Welfare of the broiler chickens, Ital. J. Anim. Sci. 8 (supplement 11), 161-173.

Minitab, 2014. Minitab Statistical Software version 17. Minitab Inc., State College, Pennsylvania, USA.

National Chicken Council, 2005. Animal welfare guidelines and audit checklist. National Chicken Council Ed. Washington, DC, USA.

Nikolova, N., Pavlovski, Z., Milosevic, N. \& Peric, L., 2007. The quality of abdominal fat in broiler chickens of different genotypes from fifth to seventh week of age. Biotech. Anim. Hus. 23, 331-338.

Ojedapo, L.O., Akinokun, O., Adedeji, T.A., Olayeni, T.B., Ameen, S.A. \& Amao, S.R., 2008. Effect of strain and sex on carcass characteristics of three commercial broiler reared in deep litter system in the derived savannah area of Nigeria. World J. Agric. Sci. 4(4), 487-491.

Olawumi, S.O. \& Fagbuaro, S.S., 2011. Productive performance of three commercial broiler genotypes reared in the derived savannah zone of Nigeria. Int. J. Agric. Res. 6, 798-804.

Onbasilar, E., Poyraz, E., Erdem, O. \& Ozturla, H., 2008. Influencing of lighting periods and stocking densities on performance, carcass characteristics and some stress parameters in broilers. Arch. Geflügelk. 72, 198-200.

Peters, S.O., Idowu, O. M.O., Brilliant, O.A., Egbede, R.O. \& Fafiolu, A.O., 2010. Genotype and sex effect on gastrointestinal nutrient content, microflora and carcass traits in Nigerian native chickens. Int. J. Poult. Sci. 9(8), 731-737.

Puron, D., Santamaria, R., Segura, J.C. \& Alamilla, J.L., 1995. Broiler performance at different stocking densities. J. Appl. Poult. Res. 4, 55-60.

Rambau, M.D., Mudau, M.L., Makhanya, S.D. \& Benyi, K., 2016. Effects of stocking density and daily feed withdrawal periods on the performance of broiler chickens in a semi-arid environment. Trop. Anim. Health Prod. 48(8), 15471554.

Rondelli, S., Martinez, O. \& Garcia, P.T., 2003. Effect on productive parameters, carcass and body fat composition of two commercial broiler lines. Rev. Bras. Cienc. Avic. 5(3), 169-173.

Sam, I.M., Akpa, G.N., Alphonsus, C.G., Iyeghe-Erakpotobor, I. \& Agubosi O.C.P., 2010. Effect of sex separation on growth performance and carcass characteristics of broilers raised to maturity. Contin. J. Anim. Vet. Res. 2, 35-40.

Shafey, T.M., Alodan, M.A, Hussein, E.O.S. \& Al-Batshan, H.A., 2013. The effect of sex on the accuracy of predicting carcass composition of Ross broiler chickens. J. Anim. Plant. Sci. 23, 975-980.

Shim, M.Y., Tahir, M., Karnuah, A.B., Miller, M., Pringle T.D., Aggrey, S.E. \& Pesti. G.M., 2012. Strain and sex effects on growth performance and carcass traits of contemporary commercial broiler crosses. Poult. Sci. 91 (11), 29422948.

Siaga, R., Baloyi, J.J., Rambau, M.D. \& Benyi, K., 2017. Effects of stocking density and genotype on the growth performance of male and female broiler chickens. Asian J. Poult. Sci. 11, 96-104.

Tong, H., Lu, J., Zou, J.M., Wang, Q. \& Shi, S.R., 2012. Effects of stocking density on growth performance, carcass yield and minute status of local chicken. Poult. Sci. 91, 667-673.

Yakubu, A., Ayoade, J.A. \& Dahiru, Y.M., 2010. The influence of genotype and population density on growth performance and carcass characters of broiler chickens in north central Nigeria. Trop. Anim. Health Prod. 42, 719-727. 